\title{
Businesswomen and theIncome Generating Activity in Buton Regency of Indonesia
}

\author{
Fatmawati Wardihan', Dewi Wagola ${ }^{2}$, Muhammad Agung Ady Mangilep ${ }^{3}$ \\ \{fatmawatiwardihan@yahoo.com ${ }^{1}$, dewiwagoladewi123@gmail.com², agungam@fe.unhas.ac.id ${ }^{3}$ \} \\ Faculty of Economics and Business, Hasanuddin University, Makassar, Indonesia
}

\begin{abstract}
This study is aimed to determine the effect of capital, working hours, technologyand sales strategies on businesswomen incomes. Our research method is quantitative. The data used are primarydata obtained by interviews and several literature studies. Multiple linear regression analysis is used to analyze data. The result of analysis shows that capital, working hour and duration of business partially have a positive and significant effect on businesswomen income. Simultaneously,the model has a positive and significant effect.
\end{abstract}

Keywords:

businesswoman, entrepreneurship, labor supply

Article Received: 18 October 2020, Revised: 3 November 2020, Accepted: 24 December 2020

\section{Introduction}

Women participations on generating enough income for their families havebecomean important ap in development programs supported by the United Nations. In Indonesia, women rolesin business activitieshave beenoccurred in traditional markets. In this digital technology era, it is interesting to see the intersection of digital technology used and traditional businesses techniques to improve the revenue of businesswomen.

Objectives of this study are to analyze some variables that affecting businesswomen incomes such as capital, working hours, experience and technology and sales strategies. This research explores which variables have a significant impact on income-generating.By measuring the impact of technological and nontechnological variables on income-generating, businesswomen can be helped to determine their strategies to increase income.

Wardihan (2018) mentioned the role of businesswoman in the market system. Management of working hours units needs to be considered because the management of working hours that have not been maximized will result in waste in work (Dwitasari and Indrajaya, 2017). The higher the time spent by businesswomen to work, the more opportunities for businesswomen to obtain additional income (Dewi, 2012). Where working hours can be interpreted as the time devoted or spent to work. In general, a person can work in a day 6 to 8 hours and the rest is used for family and rest (Dwitasari and Indrajaya, 2017). In addition to working hours, factor in operating time is important to influence the revenue because the longer a person carries on business then it will have a more mature strategy and increasingly have a relationship or more customers (Setiaji and Fatuniah, 2018). Nurhuda, et al (2018) stated labors, including female labors, can move to other regions or countries in Indonesia.

In trading activities, it is also important technology factors and sales strategies to increase sales of goods that can affect income by using 4 components of marketing mix such as products, prices, places and promotions of the merchandise (Sharma,2016). The one that determines the level of business success and failure is choosing the right and strategic business location. However,the adoption of new technology may not be accepted by everyone (Mangilep, 2015). Ady (2015) stated that technology may be accepted to keep the existence of a business.

Hypotheses for this research are described below. 
1. It is assumed that the capital (X1) has a positive and significant effect on the income of businesswomen in Buton Regency.

2. It is assumed that the working hour (X2) have a positive and significant effect on the income of businesswomen in Buton Regency.

3. It is assumed that the experience (X3) has a positive and significant effect on the income of businesswomen in Buton Regency.

4. It is assumed that there are differences in the income of businesswomen caused by the use of technology and sales strategies.

\section{Research Methodology}

This study uses a quantitative approach. Quantitative methods are used to quantify the object of research(MacDonald and Headlam, 2011). Quantitative methods use quantitative data and generate results from a sample for a particular population. This is done by measuring events from various observations and opinions on the chosen sample or overall results.

This study seeks to test the application of existing theories, so that the concepts and indicators are based on existing theories. Indicators is a form of phenomena that arise from the concept of theory (Walliman, 2011), will be implemented in the form of research variable that this study makes the relationship of several independent variables and a dependent variable. Research variables are measurable characteristics or attributes of what is different for different research subjects with independent variables as variables that answer what questions are changed and the dependent variable answers what questions are observed (MacDonald and Headlam, 2011).

The independent variables used in this study are the factors that influence the sales of businesswomen. Each variable has a value as a unit in the measurement of variables (Walliman, 2011). In this study, values of each variable are included in the calculation using a predetermined analysis tool. The data used in this study are primary data. Primary data is data that has been observed, experienced or recorded close to the real situation in revealing the truth (Walliman, 2011).In this study, primary data was obtained from interrogations (investigations) to be conducted by giving questions to respondents using questionnaire tools.

Primary data is data obtained directly from a field research. Primary data used in this study were obtained directly through questionnaires or interviews, which includes personal data of respondents. The questionnaire was intended to determine the financial condition of the respondents and also their family's role in increasing their income. Respondents are businesswomen at the Kaloko Market in Pasarwajo District and Ambuau Market in South Lasalimu District of Buton Regency.

Secondary data is data obtained indirectly. In this research, secondary data comes from literature from government published data, such as Central Bureau of Statistic of Buton Regency, internet and books, and articles related to the title.

Population of this research is all participants who meet the criteria in accordance with the research conducted (Alvi, 2016). The population in this study is the businesswomen in Market Kaloko and Markets Ambuau Buton as much as 198 people. Samples taken from the population must be able to represent a large number of participants population by research in research (Alvi, 2016). Sample size determination is done to provide the number of participants who can have an impact on the population (Noordzij etc. 2010). In determining sample size, there are several aspects that need to be considered, such as: population proportions, degree of accuracy, variation of population and level of trust (NAO, 1999).The proportion of population is the proportion of a part in the population that displays the attributes sought in the study (NAO, 1999). Margin of error or precision is a measure of the possible difference between the sample estimation results and the actual population value (NAO, 1999). The lower margin of error then the 
accuracy will be higher. Generally research uses accuracy of 5 percent. Population variations provide distance between opinions or values in the population (NAO, 1999). The lower the variation, the more accurate the sample size will be. The level of confidence (level of confidence) shows how much the researcher believes in the description of the population estimated by the sample associated with its accuracy (NAO, 1999). The greater the level of trust, the research results are considered more accurate. Generally the level of trust used in various studies is 95 percent. The sample size can be determined using a sample size table based on certain combinations of accuracy, confidence level and population proportion or variation by 50 percent (Taherdoost, 2017). For the determination of samples from a population of 178 with a level of confidence of 95 percent, precision of 5 percent and variation of 50 percent, the nearest sample size will be obtained as many as 108 samples.

This research is quantitative research so that in sampling use a type of probability sampling. This type of sampling is very convincing to represent the population and use random methods in conducting sample selection (Walliman, 2011). For sampling, it is necessary to pay attention to the sampling frame. Sampling frames or sampling frames are lists of members of the population as sources for sample selection (MacDonald and Headlam, 2011). Sampling frames for this study are as follows:

1. Female vegetable sellers are 52 people or 29 percent of the population .

2. Women fish sellers are 43 people or 24 percent of the population.

3. Women stall sellers are 40 people or 22 percent of the population.

4. Women in clothing, shoes and sandals are as many as 43 people or 24 percent of the population.

Because probability sampling uses sample grouping, sampling should use stratified sampling. With a sample size of 108 , the value is distributed on the sample frame with the following details:

1. Vegetable sellers are 32 people.
2. Fish sellers are 26 people.

3. Make-up tools sellers are 24 people.

4. Clothing, shoes and sandalssellers are 26 people.

Furthermore, to determine which businesswomen will be selected from each sample size in each sample group, it will be selected using a random method.

The interview method is used to find data by asking a number of questions to the respondent. The research was conducted by interviewing the businesswomen in the Kaloko market. This method is also intended for respondents who cannot read and write.

Questionnaires are data collection techniques that are carried out by giving a set of questions or written statements to the respondent to answer. The questionnaire given is structured by combining closed and open questions aimed at understanding the condition of businesswomen in Kaloko Market and Ambuau Market.

A library research is a technique of collecting data from various literature in order to obtain theories that are relevant to the problems examined through books, journals, and other reading materials. Most of secondary data came from "Angkatan Kerja Kabupaten Buton Tahun 2018“ published by Indonesian Central Bureau of Statistics.

Multiple linear regression methodis used to analyze primary data. This method develops a relationship between the dependent variable and the independent variable, then the data collection is done by multiple regression analysis methods expressed in the form of mathematical functions as follows:

$$
\mathrm{Y}=\mathrm{f}\left(\mathrm{X}_{1}, \mathrm{X}_{2}, \mathrm{X}_{3}, \mathrm{X}_{4}\right)(1)
$$

Then the function of the equation is stated in the $\mathrm{Y}$ and $\mathrm{X}$ relations as follows:

$\operatorname{Ln} \mathrm{Y}=\beta 0+\beta 1 \operatorname{Ln} \mathrm{X} 1+\beta 2 \mathrm{X} 2+\beta 3 \mathrm{X} 3+$ $\beta 4 \mathrm{X} 4+\mu(2)$

Where:

$\mathrm{Y}=$ Female Seller (Rupiah) Income

X 1 = Capital (Rupiah / week )

X 2 = Working hours (Hours / week )

X $3=$ Duration of Business (years) 
X 4 = Technology and Sales Strategy (dummy variable 1 = who usestechnology and sales strategy and $0=$ who do not use technology and sales strategy)

$\mu=$ Error Rate ( error )

$\beta 0=$ Constants

$\beta 1-\beta 4=$ Regression coefficient of each independent variable

\section{Result and Discussion}

Results of data calculation based on regression model show the significance value of the variable $\mathrm{X} 1$ is 0.000 , the value shows the variable $\mathrm{X} 1$ (Sig) $<\alpha 0.05$ so that the hypothesis is accepted. This means that the variable X1 (capital) has a significant effect on the income of businesswomen with a regression coefficient of 0.577 . This means that when there is an increase in capital of 1 percent, it will increase income by 0.577 .

The significance value of the variable $\mathrm{X} 2$ is 0.000 , so this value shows variable $\mathrm{X} 2$ (Sig) $<\alpha$ 0.05 so the hypothesis is accepted. This means that the variable X2 (working hours) has a significant effect on the income of businesswomen with a regression coefficient of 0.025 . This means that when there is an increase in working hours of 1 percent, it will increase income by 0.025 .

The significance value of the variable $\mathrm{X} 3$ is 0.000 so this value shows the variable $\mathrm{X} 2(\mathrm{Sig})<$ $\alpha 0.05$ so the hypothesis is accepted. This means that the variable X3 (duration of business) has a significant effect on the income of businesswomen with a regression coefficient of 0.055 . This means that when there is an increase in working hours of 1 percent, the income will increase by 0.055 .

The significance value of the $\mathrm{X} 4$ dummy variable is 0.635 , so this value shows the variable $\mathrm{X} 4(\mathrm{Sig})>\alpha 0.05$ so the hypothesis is rejected. This means that the variable $\mathrm{X} 4$ (technology and sales strategy ) there is no difference in income of businesswomen who use technology and sales strategies or those who do not. Based on the results of the statistical tests above, the regression analysis model is as follows:

$$
\mathrm{Y}=4.548+\mathrm{X} 1+0.577 \mathrm{X} 2+0.055 \mathrm{X} 3+
$$
$0.088 X 4+\mu \ldots(3)$
Based on the results of the above research there are three independent or independent variables that have a significant effect on the dependent or dependent variables, namely capital, working hours, and length of business, so that the results are in accordance with the initial hypothesis in the previous chapter. The nonconforming to the initial hypothesis is a technology dummy variable and sales strategy, where the variable does not significantly influence the dependent variable, namely the income of businesswomen.

Statistical test $F$ with significance of $0.000 \mathrm{~b}<$ $\alpha 0.05$ then the hypothesis is accepted. This means that independent or independent variables, namely capital, working hours, length of business and technology dummy variables and sales strategies have an effect on simultaneously on the dependent or dependent variable, namely the income of businesswomen.

The coefficient used in this study is R Square which shows a value of 0.734 , meaning free or independent variables, namely capital, working hours, long effort, dummy technology and sales strategies directly affect the income of businesswomen (the dependent variable or dependent) of 73.4 per cent while the rest 26.6 percent is explained by other factors not included in the model.

The results of the above statistical tests show that the capital variable influences the income of businesswomen, this is seen from the regression coefficient value which is positive at 0.577 . Previously on the initial hypothesis it was assumed that the capital variable had a positive and significant effect on the income of businesswomen, based on this, the hypothesis was accepted.

Capital is the most important thing in running a business including trading. The capital used can be in the form of own capital, but if the capital itself is insufficient it can be supplemented by loan capital from other parties. The capital that is used daily in trading business is referred to as current capital, namely assets or assets that are needed by sellers to carry out buying and selling 
activities. The current capital used to buy merchandise that continues that eventually will affect the income in this case the seller.

The greater the working capital used will be followed by the increase in merchant income. The assumption is that with large capital, it will increase the variety of merchandise so that it will attract buyers to buy existing merchandise so that income will increase.

The results of the statistical tests above show that working hours variables affect the income of businesswomen, this is seen from the regression coefficient value which is positive at 0.025 . Previously on the initial hypothesis it was assumed that working hours variable had a positive and significant effect on the income of businesswomen, based on this, the hypothesis was accepted.

In addition to capital, the merchant's income is also determined by the length of work or working hours. The more the number of working hours used means to be more productive, so the higher the working hours of women who lived sellers, the higher the income. This shows that the relationship between working hours and income is positive.

The results of the statistical tests above show that the old variable of business has an effect on the income of businesswomen, this is seen from the regression coefficient value which is positive, which is 0.055 . Previously on the initial hypothesis it was assumed that the old variable of business had a positive and significant effect on the income of businesswomen, based on this the hypothesis was accepted.

The duration of a business can give rise to a business experience, knowledge, and be able to make decisions in every condition and condition. In addition, the longer the field of trading business increases the more knowledge about consumer tastes and behavior and the more business and customer relations that can increase revenue. This shows that the long business relationship to income is positive.

The results of the statistical tests above show that technology variables and sales strategies do not affect the income of businesswomen. The regression coefficient value on this variable is positive, which is 0.088 . Previously in the initial hypothesis it was alleged that there were differences in businesswoman income caused by the use of technology and sales strategies. This is not in accordance with the results of the study, the hypothesis is rejected.

The technology referred to in this study is a cellphone used by businesswomen in the Kaloko Market and Ambuau Market while the sales strategy in this study is a marketing mix component in the form of products, prices, places and promotions.

In this day and age people are easy to use the internet and almost everyone uses mobile phones. Many others are using social media as a trading business like Facebook and Instagram. In the market Kaloko and Markets Ambuau, businesswomen assume that mobile phones and social medias cannot be linked to their businesses, especially for a promotion, providing information about the product (merchandise), price, place and prefer trading in the real world and not in the cyberspace. They also assume that many people can reach their merchandise on the market.

\section{Conclusion}

This research concludes that capital influences income of businesswoman. Because the greater working capital owned by businesswomen, the more merchandisesare obtained and more possibilities of obtaining higher income. Working hours affects the income of businesswoman. The higher the female trader is in devoting her time to work, the more likely it is to get higher income. A business experience affects the income of businesswoman caused by the longer trade period the more buyers turn into regular customers and that will affect the high and low income.Technology and sales strategies has no difference results in income between traders who use technology and sales strategies and who do not use technology and sales strategies. Income of businesswomen is simultaneously affected by 
capital, working hours, experience, and technologyand sales strategies.

Some ideas can be suggested from results of this research. Businesswomen who have a higher income should maintain the level of sales, whereas low income merchants are expected to augment their existing merchandise to raise capital.Consumers should be careful in choosing items offered by sellers regardingtheir price and quality. Government agencies and bankersshould provide more aids and loans for businesswomen. The later researchers should investigate more factors other than in this research.

\section{References}

[1] Ady, M. M. A. (2015). Findings in Interviews on Motivation of Farmers for the Improvement of Paddy Rice Quality and the Implementation of New Methods of Paddy Rice Production in the Chiba Prefecture. 人文社会科学研究 第 31 号. Retrieved from https://core.ac.uk/download/pdf/9706498 1.pdf

[2] Alvi, M (2016). A Manual for Selecting Sampling Techniques in Research. MPRA Paper No.70218. Retrieved from https://mpra.ub.unimuenchen.de/70218/1/MPRA paper 70218.pdf. Posted March 252016 17:01 UTC.

[3] Dewi, P. M. (2012). Partisipasi Tenaga Kerja Perempuan dalam Meningkatkan Pendapatan Keluarga. Jurnal Ekonomi Pembangungan Vol.5 No.2.

[4] Dwitasari, N. M. M., Indrajaya I. G. B. (2017). Analisis Produksi terhadap Pendapatan Pengrajin Dulang Fiber di Desa Bresela Kabupaten Gianyar. Jurnal Ekonomi PembangunanUniversitas Udayana Vol. 6 No. 5 ISSN: 2303-01 78

[5] Fatmawati Wardihan (2018) The Determinants of Female Labour Supply in Makassar City. IJSR, Volume 7 Issue 2, February 2018.
[6] Mangilep, M. A. A. (2015). Socioeconomic Problems on Adoption of New Technologies for Production of Paddy Rice by Farmers in Upland Areas of South Sulawesi. 千葉大学人文社会科学研究, 千葉大学人文社会科学研究 (30), 150157 , 2015-03, 千葉大学大学院人文社会科学研究科.

Retrieved from https://ci.nii.ac.jp/naid/120005940591/

[7] MacDonald, S, Headlam, N (2011). Research Methods Handbook. ISBN : 1870053656. Center for Local Economic Strategies. http://www.cles.org.uk/wpcontent/uploads /2011/01/ResearchMethods-Handbook.pdf

[8] NAO (1999). A Practical Guide to Sampling. National Audit Office, Statistical \& TechnicalTeam. Retrieved from http://www.nao.org.uk/wpcontent/uploads/2001/06/

SamplingGuide.pdf

[9] Noordzij, M, Tripepi, G, Dekker, F. W., Zoccali, C., Tanck, M. W., Jager, K. J. (2010). Sample Size Calculations: Basic Principles and Common Pitfalls. Doi: 10.1093/ndt/gfp732. Retrieved from https://www.researchgate.net/publication/ 46403233

[10] Nurhuda, Madris, Fatmawati Wardihan (2018) Determinants of Labor Migration in Overseas in Indonesia. Quest Journals, Journal of Research in Humanities and Social Science Volume 6 Issue 12 (2018) pp.:37-4, ISSN (Online) :23219467, www.questjournals.org.

[11] Setiaji, K., Fatuniah, A. L. (2018). Pengaruh Modal, Lama Usaha dan Lokasi terhadap Pendapatan Pedagang Pasca Relokasi. Jurnal Pendidikan Ekonomi dan Bisnis. Retrieved from http://journal.unj/unj/index.php/jpeb. Posted 01 March 2018 
[12] Sharma, DK (2016) Relevance Of Underutilized Fruit Crops For Sustainable Farm Income In Tribal Areas Of Western India. International Journal of Retailing \& Rural Business Perspectives (C) Pezzottaite Journals. Volume 5, Number 1ISSN (Print): 22790934, (Online): 2279-0942

[13] Taherdoost, H (2017) Determining Sample Size How to Calculate Survey Sample Size. International Journal of Economics and Management Systems Vol.2 ISSN: 2367-8925

[14] Walliman, N. (2011). Research Methods: The Basics. ISBN : 0 -203-83607-3. Routledge, London and New York. Retrieved from https://edisciplinas.usp.br/pluginfile.php/ 2317618/modresource/content/1/BL OCO\% 202_Research\% 20Methods\% 20The\% 20Basics. Pdf. 